JPPI Vol 7 No 2 (2017) 129-142

\author{
Jurnal Penelitian Pos dan Informatika \\ 771/AUI/P2MI-LIPI/08/2017 \\ $32 \mathrm{a} / \mathrm{E} / \mathrm{KPT} / 2017$ \\ e-ISSN 2476-9266 \\ p-ISSN: 2088-9402 \\ DOI: $10.17933 /$ jppi.2017.070205
}

\title{
PENERAPAN TRACKING BUS "TRANS MAMMINASATA" DENGAN MEMANFAATKAN TEKNOLOGI GOOGLE MAPS API BERBASIS MOBILE WEB DI KOTA MAKASSAR
}

\section{IMPLEMENTATION OF TRACKING BUS "TRANS MAMMINASATA" USING TECHNOLOGY GOOGLE MAPS API WEB MOBILE-BASED IN MAKASSAR}

\author{
${ }^{1}$ Rismayani, ${ }^{2}$ Hasyrif SY \\ ${ }^{12}$ Program Studi Sistem Informasi - Sekolah Tinggi Manajemen Informatika dan Komputer, Dipanegara Makassar \\ ${ }^{12}$ Jl. Perintis Kemerdekaan Kemerdekaan Km.9 Makassar, Tamalanrea Makassar 90000 Indonesia \\ 'maya_setya@ymail.com
}

Naskah Diterima: 11 Oktober 2017; Direvisi : 7 Desember 2017; Disetujui : 12 Desember 2017

\begin{abstract}
Abstrak
Trans Mamminasata adalah sebuah layanan Bus Rapid Transit (BRT) yang telah diluncurkan oleh pemerintah Provinsi Sulawesi Selatan guna melayani kebutuhan transportasi umum bagi para pengguna angkutan BRT di wilayah Maros, Makassar, Sungguminasa dan Takalar (Mamminasata). Adapun permasalahan dalam penelitian ini adalah bagaimana memberikan informasi kepada masyarakat pengguna layanan trans mamminasata mengenai titik-titik lokasi keberadaan bus Trans Mamminasata secara periodik sehingga memudahkan masyarakat untuk mengetahui tracking dan keberadaan dari bus Trans Mamminasata. Metode atau teknologi yang digunakan adalah Google Maps API untuk menetahui titik-titik keberadaan bus Trans Mamminasata, Google Maps API adalah kumpulan API yang memungkinkan seseorang menghamparkan data di peta khusus google dan berbasis mobile. Hasil dari penelitian ini adalah dengan memanfaatkan teknologi Google Maps API yang berbasis Mobile maka masyarakat pengguna bus Trans Mamminasata dapat mengetahui titik-titik keberadaan bus Trans Mamminasata secara periodik serta mengetahui informasi tracking yang dilewati oleh bus Trans Mamminasata. Berdasarkan hasil kuesioner yang diambil sampel 25 responden dari masyarakat pengguna bus Trans Mamminasata untuk mengetahui tingkat manfaat dari sistem tracking adalah $82 \%$ sangat bermanfaat, $15 \%$ bermanfaat, $3 \%$ cukup bermanfaat dan $0 \%$ tidak bernanfaat.
\end{abstract}

Kata kunci: Google Maps API, Tracking Bus, Mobile Web, Bus Rapid Transit (BRT)

\begin{abstract}
Trans Mamminasata is a Bus Rapid Transit (BRT) service that has been launched by the provincial government of South Sulawesi to serve public transportation needs for BRT transport users in Maros, Makassar, Sungguminasa, and Takalar (Mamminasata) areas. The problem in this research is how to provide information to the community of Trans Mamminasata service users regarding the location points of the existence of Trans Mamminasata bus periodically to facilitate the public to know the tracking and the existence of the Trans Mamminasata bus. The method or technology used is Google Maps Fire to know the points of the existence of Trans Mamminasata busses, Google Maps Fire is a collection of APIs that let someone spread data on google and mobile-based maps. The result of this research is by utilizing the technology of Google Maps API based on mobile hence society of Trans Mamminasata bus user can know the existence of Trans Mamminasata period periodically and also know tracking information which passes by Trans Mamminasata. Based on the results of questionnaires, a sample of 25 respondents from Trans Mamminasata bus users to find out the benefit of the tracking system is $82 \%$ very useful, $15 \%$ useful, $3 \%$ useful enough and $0 \%$ not useful.
\end{abstract}

Keywords: Google Maps API, Tracking Bus, Web Mobile, Bus Rapid Transit (BRT) 


\section{PENDAHULUAN}

Bus Rapid Trans (BRT) atau dikenal dengan busway Mamminasata saat ini telah beroperasi pada koridor 2,3,4 dan 11, sebanyak 7(tujuh) bus pada koridor 2, 8(delapan) bus koridor 3, 2(dua) bus koridor 4 dan 2(dua) bus koridor 11 yang telah melayani penumpang atau pengguna anggukatan umum di kota makassar. BRT adalah bantuan dari kementrian yang diberikan kepada 3 kota yaitu Surabaya, Denpasar dan Makassar. Pada Makassar BRT di sebut dengan Bus Trans Mamminasata, Trans Mamminasata beroperasi di wilayah Makassar, Maros, Sungguminasa dan
Takalar (Mamminasata). Sebagai tahap awal sekaligus uji coba, jurusan yang dioperasikan baru 4 koridor yaitu koridor 2, 3, 4 dengan bus yang bisa menampung 78 penumpang dan koridor 11 dengan bus yang bisa menampung 33 penumpang. Tarif yang dikenakan ke penumpang pada saat pertama beroperasi adalah Rp 5.000 per satu kali jalan, namun sekarang sesuai dengan penurunan harga bbm (bahan bakar minyak) maka tarif yang dikenakan adalah Rp 4.500 per satu kali jalan.

Adapun tracking/jalur dan rute dari bus Trans Mamminasata dapat dilihat pada tabel berikut ini:

Tabel 1. Jalur Koridor Trans Mamminasata

\begin{tabular}{|c|c|}
\hline Koridor & Rincian Jalur \\
\hline Koridor 1 & $\begin{array}{l}\text { Bandara-Tol-Jl.Nusantara-Jl. Ahmad Yani-Jl. Jenderal Sudirman-JlHaji Bau-Jl Metro Tanjung Bunga-Trans Studio-Mal } \\
\text { GTC (pergi). Mal GTC-Trans Studio-Jl. Metro Tanjung Bunga-Jl Penghibur-Jl Pasar Ikan-J1 Ujung Pandang-J1 } \\
\text { Nusantara-Tol-Bandara (Pulang). }\end{array}$ \\
\hline Koridor 2 & $\begin{array}{l}\text { Mal GTC-Trans Studio-Jl Metro Tanjung Bunga-Jl Penghibur-Jl Pasar Ikan-Jl Ujung Pandang-Jl Ahmad Yani-Jl } \\
\text { Bulusaraung-Jl Masjid Raya-J1 Urip Sumoharjo-Jl AP Pettarani-Jl Boulevard-Mal Panakukkang (pergi). Mal } \\
\text { Panakukkang-Jl Boulevard-Jl AP Pettarani-Jl Urip Sumoharjo-Jl Bawakaraeng-Jl Jenderal Sudirman-Jl. Sam Ratulangi- } \\
\text { J1 Kakatua-Jl Gagak-J1 Nuri-Jl Rajawali-J1 Metro Tanjung Bunga-Trans Studio-Mal GTC (pulang) }\end{array}$ \\
\hline Koridor 3 & $\begin{array}{l}\text { Terminal Daya-Jl. Perintis Kemerdekaan-Jl. Urip Sumoharjo-Jl. AP Pettarani-Jl. Sultan Alaudin-Jl. Gowa Raya- } \\
\text { Terminal Pallangga (Pulang Pergi) }\end{array}$ \\
\hline Koridor 4 & Terminal Daya-Jl Perintis Kemerdekaan-Bandara-J1 Poros Makassar Maros-Terminal Maros (Pulang Pergi) \\
\hline Koridor 5 & $\begin{array}{l}\text { Untia-Terminal Panampu-Jl. Tinumbu-Jl Ujung-Jl Bandang-Jl Veteran Utara-Jl Veteran Selatan-Jl.Sultan Alaudin-Jl } \\
\text { Gowa Raya-Terminal Pallangga (Pulang Pergi) }\end{array}$ \\
\hline Koridor 6 & Terminal Pallangga-Jl.Poros Takalar-Jl Raya Bontomanai-Barombong-Mal GTC (Pulang Pergi). \\
\hline Koridor 7 & Terminal Pallangga-Jl Poros Takalar-Terminal Takalar (Pulang Pergi). \\
\hline Koridor 8 & Terminal Takalar-Galesong Selatan-Galesong Utara-Barombong-Mal GTC (Pulang Pergi). \\
\hline Koridor 9 & Terminal Daya-Jl Lingkar Tengah-Bontomanai-Jl Poros Takalar-Terminal Pallangga (Pulang Pergi). \\
\hline Koridor 10 & Terminal Daya-Jl Lingkar Luar-Bontomanai-J1 Poros Takalar-Terminal Pallangga (Pulang Pergi). \\
\hline Koridor 11 & Terminal Maros-Jl By Pass Mamminasata- Bontomanai-Barombong (Pulang Pergi). \\
\hline
\end{tabular}

(Sumber Data : Database Perum Damri Makassar, 2016)

Terkadang kendala yang dihadapi penumpang bus Trans Mamminasata adalah waktu menunggu yang sangat lama di halte yang telah disediakan, karena jadwal operasi armada bus Trans Mamminasata sering tidak tepat waktu sehingga para penumpang terkadang bosan untuk menunggu dengan waktu yang tidak jelas.

Google Maps API berbasis Mobile merupakan sistem informasi dapat memberikan solusi yang dapat di gunakan para penumpang untuk mengetahui tracking dan titik keberadaan bus 
Trans Mamminasata sehinnga para penumpang tidak harus menunggu lama di halte. Google Maps API memanfaatkan GPS (Global Positioning System) untuk mengirimkan tracking dan titik posisi keberadaan dari bus Trans Mamminasata.

Dengan perkembangan teknologi informasi sekarang ini termasuk perkembangan perangkat smartphone, sistem informasi yang dibuat untuk mengetahui tracking dan titik posisi Trans Mamminasata berbasis mobile web dengan menggunakan teknologi dari Google Maps API.

Adapun masalah pada penelitian ini adalah Bagaimana membuat dan mengimplementasikan sistem informasi berbasis mobile web yang dapat membantu para penumpang untuk mengetahui tracking atau titik posisi dari bus Trans Mamminasata, penerapan pemanfaatan teknologi Google Maps API untuk menampilkan peta posisi tracking dari bus Trans Mamminasata dan merancang sistem informasi atau aplikasi yang dibuat dapat memberikan informasi yang akurat kepada para penumpang mengenai tracking bus Trans Mamminasata

Adapun beberapa penelitian yang terkait adalah Prediksi pengguna Trans serbagita dengan dengan metode Adative Neuro Fuzzy Inference System, pada penelitian ini dibuat sistem untuk peramalan jumlah penumpang pada trans serbagita dengan metode ANFIS (Hidayat, Kencana, \& Jayanegara, 2013). Kemudian Penelitian yang berjudul Evaluasi pelayanan transit antar koridor bus Rapid Transit Trans Semarang, pada penelitian ini menjelaskan mengenai evaluasi pelayanan proses dan waktu transir dari bus Trans semarang (Salasa, Wakhidho, Bagus Hario Setiadji, \& Epf. Eko Yulipriyono, 2015). Selanjutnya penelitian yang berjudul Tingkat kepuasan pengguna Trans
Jakarta, pada penelitian ini membahas penghitungan tingkat kepuasan dari pengguna Trans Jakarta (Haroen et al., 2014). Kemudian penelitian yang berjudul Estimasi waktu kedatangan Bus Rapid Transit menggunakan bus sebagai sensor node di kota Makassar, pada penelitian ini membahas mengenai estimasi atau perkiraan dari waktu kedatangan bus Trans Mamminasata (Ridwan, 2017). Penelitian yang berjudul Bus dispatching at timed transfer transit stations using bus tracking technology, pada penelitian ini membahas mengenai teknologi yang dapat mengontrol waktu transit secara real time (Dirgahayani, 2013). Kemudiam pada penelitian yang berjudul sistem informasi geografi untuk evaluasi lokasi shelter bus trans Semarang, pada penelitian ini membahas pemetaan shelter bus Trans Semarang, menganalisi antar hubungan lokasi shelter dengan potensi bangkitan dan tarikan serta mengevaluasi lokasi shelter bus Trans Semarang menggunakan sistem informasi geografi (Firmanda \& Rahardjo, 2013). Pada penelitian yang berjudul Pemetaan Titik Perumahan Pada Kota Makassar Menggunakan Google Maps API, penelitian ini membahas mengenai penyebaran titik perumahan di kota Makassar dengan memanfaatkan teknologi Google Maps API (Sy \& Rismayani, 2015). Kemudian penelitian yang berjudul Aplikasi berbasis mobile untuk pencarian rute angkutan umum kota Makassar menggunakan algoritma Depth First Search, pada penelitian ini membahas mengenai pencarian rute angkutan umum yang ada di kota Makassar menggunakan algoritma Depth First Search (Rismayani \& Ardimansyah, n.d.). Selanjutnya penelitian yang berjudul Selanjutnya penelitian yang berjudul pemanfaatan teknologi Google Maps Api untuk aplikasi laporan kriminal 
berbasis android pada Polrestabes Makassar, pada penelitian ini membahas aplikasi laporan tindak kriminal yang terjadi di kota Makassar menggunakan teknologi Google Maps API (Rismayani, 2016).

Bus Rapid Transit (BRT) atau busway merupakan bus dengan kualitas tinggi yang berbasis sistem transit yang cepat, nyaman, dan biaya murah untuk mobilitasperkotaan dengan menyediakan jalan untuk pejalan kaki, infrastrukturnya, operasi pelayanan yang cepat dan sering, perbedaan dan keunggulan pemasaran dan layanan kepada pelanggan (Isya et al., 2013). Bus Rapid Transit (BRT), pada dasarnya mengemulasi karakteristik kinerja sistem transportasi kereta api modern. Satu sistem BRT biasanya akan dikenakan biaya 4-20 kali lebih kecil dari Light Rail Transit (LRT) dan 10-100 kali lebih kecil dari sistem kereta api bawah tanah. Istilah BRT telah muncul dari penerapannya di Amerika Utara dan Eropa. Namun, konsep ini juga ditularkan melalui dunia dengan nama yang berbeda-beda, seperti:
a. High-Capacity Bus Systems
b. High - Quality Bus Systems
c. Metro - Bus
d. Surface Metro
e. Express Bus Systems
f. Busway Systems

Google Maps adalah layanan gratis yang diberikan oleh Google dan sangat popular. Google Maps adalah suatu peta dunia yang dapat kita gunakan untuk melihat suatu daerah. Dengan kata lain, Google Maps merupakan suatu peta yang dapat dilihat dengan menggunakan suatu browser (Svennerberg, 2010). Google menyediakan berbagai API (Application Programming Interface) yang sangat berguna bagi pengembang web maupun aplikasi desktop untuk memanfaatkan berbagai fitur yang disediakan oleh Google seperti misalnya: AdSense, Search Engine, Translation maupun YouTube.

GPS atau Global Positioning System, merupakan sebuah alat atau sistem yang dapat digunakan untuk menginformasikan penggunanya dimana lokasinya berada (secara global) di permukaan bumi yang berbasiskan satelit. Dimanapun pengguna tersebut berada, maka GPS bisa membantu menunjukan arah. Layanan GPS ini tersedia gratis (Parkinson,1996).

Trans Mamminasata adalah layanan angkutan massal Bus Rapid Transit (BRT) di Kota Makassar yang mulai beroperasi pada Maret 2014. Koridor pertama yang dibuka adalah rute Mal GTC - Mal Panakkukang. Pengoperasian bus ini sudah direncanakan sejak tahun 2007, namun terus tertunda oleh berbagai faktor. Pada tahun 2011, Kementerian Perhubungan menunjuk tiga kota, yakni Padang, Surabaya dan Makassar ("Inilah Koridor Busway Makassar - JPNN.COM," n.d.).

Mobile web bertujuan untuk mengakses layanan data secara wireless dengan menggunakan perangkat mobile seperti handphone, PDA dan perangkat portable yang tersambung ke sebuah jaringan telekomunikasi selular (Suryadi dkk, 2013). Mobile web yang diakses melalui perangkat mobile perlu dirancang dengan mempertimbangkan keterbatasan perangkat mobile seperti sebuah handphone yang memiliki sebuah layar dengan ukuran yang terbatas ataupun beberapa keterbatasan pada sebuah perangkat mobile.

Mobile web umumnya berukuran ringan disetiap halamannya yang ditulis dengan Extensible Hypertext Markup Language (XHTML) atau 
Wireless Markup Language (WML) untuk mengirimkan konten ke perangkat mobile. Selain itu beberapa teknik seperti dengan menggunakan Adobe Flash Lite atau Sun J2ME yang memungkinkan untuk membuat perangkat mobile yang lebih bervariasi.

Rancangan yang digunakan adalah UML ( Unified Modelling Language), UML adalah sebuah bahasa yang berdasarkangrafik/gambar untuk memvisualisasi, menspesifikasikan, membangun, dan pendokumentasiandari sebuah sistem pengembangan software berbasis $\mathrm{OO}$ (ObjectOriented). (Ritonga, n.d.)

Tujuan penelitian ini adalah Dapat mengimplementasikan sistem informasi berbasis mobile web yang membatu para penumpang untuk mengetahui tracking atau titik posisi dari Trans Mamminasata, menerapkan pemanfaatan teknologi Google Maps API untuk menampilkan peta posisi tracking bus Trans Mamminasata dan membuat aplikasi yang memberikan informasi akurat kepada para penumpang.

Pada penelitian ini dibuat sebuah sistem tracking bus Trans mamminasata yang merupakan salah satu fasilitas angkutan umum yang masih beru beroperasi di kota Makassar, pada sistem ini akan di tampilkan rute tracking dari bus Trans Mammminasata secara periodik sehingga para penumpang dapat mengetahui lokasi bus berada dengan menampilkan peta Google Maps API yang berbasis, dengan adanya sistem tracking bus ini pula maka para penumpang tidak harus menunggu lama di halte tanpa kepastian dan dapat mengetahui lokasi bus Trans Mamminasa secara real time.

\section{METODE}

Adapun lokasi penelitian adalah berada pada wilayah kota Makassar dan Jalur Trans Mamminasata yaitu Maros, Makaasar, Sungguminasa dan Takalar dengan melibatkan instansi pemerintahan yaitu Dinas perhubungan serta bekerjasama dengan Perum Damri Kota Makassar.

Sumber data penelitian diperoleh sebagai berikut:

a. Data primer yaitu data-data yang berupa datadata jalur Trans Mamminasata, jumlah koridor beserta jalur serta halte yang tersedia di setiap tempat di wilayah Makassar

b. Data sekunder yaitu berupa literatur, artikel dan beberapa referensi yang berkaitan dan berhubungan dengan tracking bus Trans Mamminasa dan referensi mengenai Google Maps API dan juga Mobile Web.

Metode dan teknologi yang digunakan adalah Google Maps API, Google Maps merupakan layanan mapping online yang di sediakan oleh google layanan yang dapat di akses melalui situs http://maps.google.com. Layanan ini interaktif karena didalamnya peta dapat di geser sesuai keinginan pengguna, mengubah tingkat zoom, dan mengubah tampilan peta. Google Maps. menyediakan beberapa mode pada tampilan petanya. 


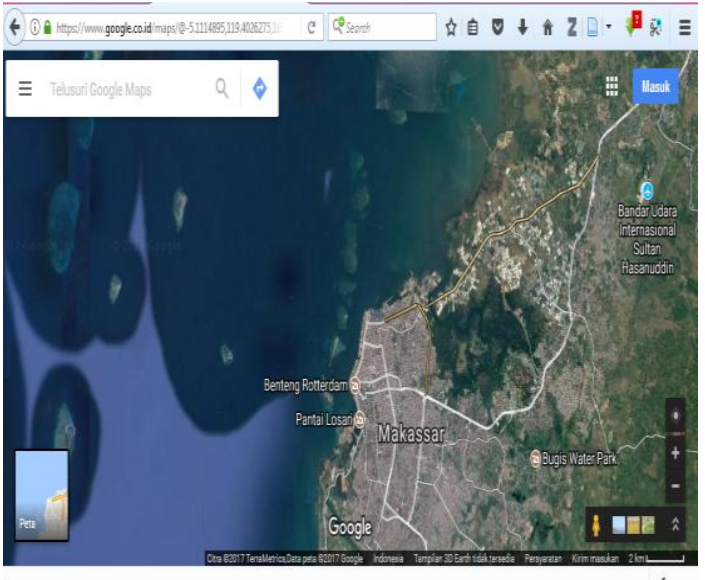

Gambar 1. Tampilan Satelit Google Maps

Google Maps API merupakan suatu fitur aplikasi yang dikeluarkan oleh google untuk memfasilitasi pengguna yang ingin mengintegrasikan Google Maps ke dalam website masing-masing dengan menampilkan data point milik sendiri. Selanjutkan digunakan sistem yang berbasis mobile web.

Tahap kegiatan penelitian yang dilakukan sebagai berikut:

a. Pengumpulan data, melakukan proses mengumpulkan data - data yang relevan dan terkait dengan penelitian yaitu mencari datadata Jumlah Bus Trans Mamminasata, Jumlah Koridor, Jalur atau rute yang di lewati setiap bus, jadwal operasi bus Trans Mamminasata dan juga informasi penempatan halte di setiap wilayah Mamminasata.

b. Analisis sistem yaitu analisis dilakukan dengan memperhatikan permasalahan dan tujuan dibangunnya sistem tracking bus Trans Mamminasata yag berbasis Mobile Web dengan memanfaatkan teknologi Google Maps API. Identifikasi input data, serta identifikasi output yang merupakan kebutuhan laporan/tampilan informasi yang diinginkan. c. Rancangan sistem yaitu dibuat rancangan dari sistem tracking bus Trans Mamminasata yang lebih terinci berdasarkan spesifikasi yang diinginkan pada tahap analisis.

d. Coding, yaitu proses coding sistem pada sistem tracking bus Trans Mamminasata berdasarkan hasil dari rancangan sistem yang telah dibuat.

e. Pengujian, dilakukan tahap internal testing (unit testing and system testing) mengenai fungsi fungsi dari sistem Tracking Bus Trans Mamminasata serta di lakukan pula pengujian kuesioner untuk mengetahui apakah sistem tracking yang dibuat bermanfaat bagi para penumpang Bus Trans mamminasata.

Untuk lebih jelas dapat dilihat pada bagan sebagai berikut :
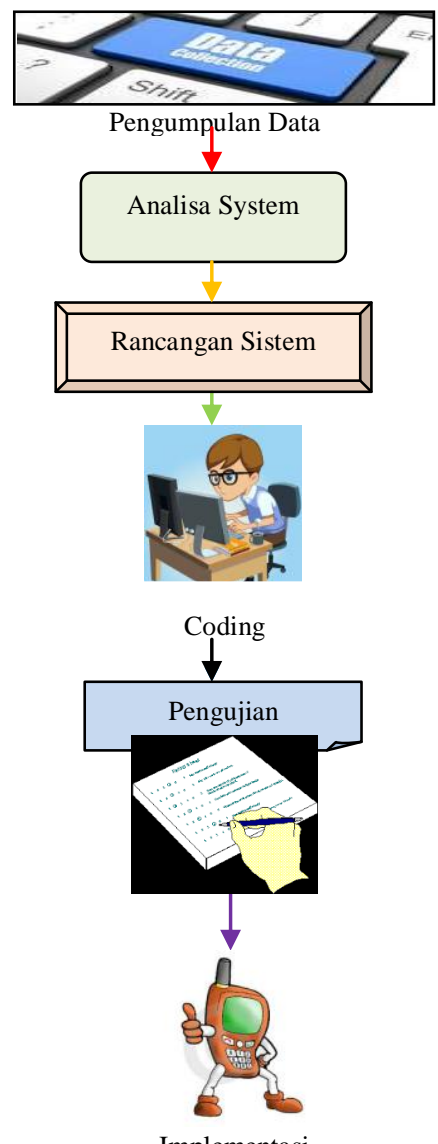

Implementasi

Gambar 2. Bagan Tahapan Penelitian 
Bahan-bahan yang digunakan untuk menyusun penelitian ini menggunakan data-data sebagai berikut :

a. Data jumlah bus Trans Mamminasata yang beroperasi.

b. Data penempatan halte bus Trans Mamminasata.

c. Data koridor dan jalur bus Trans Mamminasata.

d. Data Jadwal bus Trans Mamminasata.

Alat - alat penelitian yang digunakan untuk mendukung proses pembuatan sistem dalam penelitian ini berupa perangkat keras dan perangkat lunak sebagai berikut :

a. 1 Unit Laptop Processor Intel Atom 1.9 GHz,Harddisk 320 GB

b. 1 Buah Smartphone Android, Memory 4 GB.

c. Microsoft Windows 7

d. Dreamweaver

e. Php MyAdmin

f. Wamp5

g. Browser Mozilla

h. Urduino Uno

i. Gsm / Gprs Shield

j. External GPRS-GSM Antena

k. External GPS Antena

1. Mini Wifi

m. Alat Perancangan UML (Unified Modelling Language )

Teknik Pengujian sistem yang digunakan adalah teknik pengujian black box, black box yaitu teknik pengujian yang digunakan untuk menguji fungsional terhadap sistem baik itu fungsi sistem maupun tehadap tombol-tombol dari sistem tersebut (Simarmata, n.d.).

Selanjutnya dilakukan pengujian untuk menguji aspek availability yaitu pengujian sistem yang dapat bekerja selama 24 jam perhari, reliability yaitu mengecek link-link informasi yang terkait mengenai informasi setiap koridor dari bus Trans Mamminasata, ergonomy yaitu memberikan desain yang menarik dan nyaman bagi untuk pengguna sistem yaitu penumpang bus Trans Mamminasata, portability yaitu sistem mampu di jalankan pada berbagai jenis browser untuk admin, dan pada perangkat smartphone, memory yaitu apakah membutuhkan penyimpanan yang besar, response time yaitu sistem dapat selalu mengupdate informasi yang terkait tracking bus Trans Mamminasata yang ditampilkan pada Google Maps Api, safety dan security yaitu keamanan dari akun sistem yang ada pada admin. Selanjutnya untuk mengetahui apakah sistem bermanfaat bagi penumpang bus trans Mamminasata maka di adakan pengambilan kuesioner dari 25 orang penumpang yang sedang menunggu di halte-halte bus Trans Mamminasata dengan menggunakan rumus sebagai berikut :

$$
P=\frac{M}{N} \times 100 \%
$$

Keterangan :

$\mathrm{M}=$ Banyaknya jawaban responden untuk setiap soal

$\mathrm{N}=$ Jumlah responden

$\mathrm{P}=$ Nilai persentase

Dengan range penilaian sebagai berikut :

Tabel 2. Range Penilaian

\begin{tabular}{ccc}
\hline No & Nilai & Keterangan \\
\hline 1 & 4 & Sangat Bermanfaat \\
2 & 3 & Bermanfaat \\
3 & 2 & Cukup Bernanfaat \\
4 & 1 & Tidak bermanfaat \\
\hline
\end{tabular}


Arsitektur sistem atau gambaran umum dari sistem yang di buat pada penelitian ini adalah :

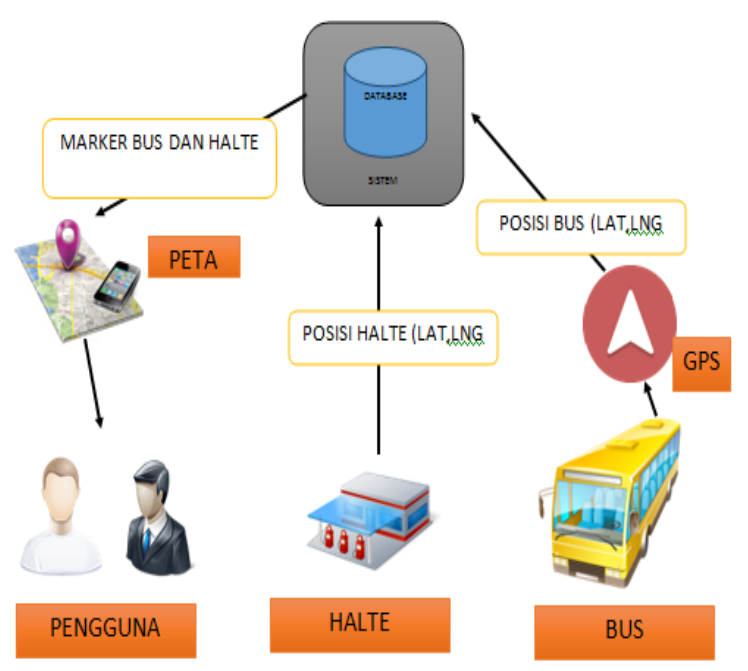

Gambar 3. Arsitektur Sistem

Prinsip kerja :

1. Setiap halte punya titik koordinat latitude dan longitude masing-masing. Setiap titik ini disimpan pada database dan data posisi halte akan di load oleh aplikasi untuk ditampilkan di peta.

2. Pada setiap bus akan di pasang GPS dimana GPS tersebut akan mengirim titik kordinat ke database aplikasi via internet, pengiriman ini dilaksanakan periodical, setiap 1 menit akan melakukan update posisi barunya ke server aplikasi.

3. Marker halte (posisi halte) akan ditampilkan di peta berdasarkan posisi di database.

4. Marker bus (posisi bus) akan ditampilkan di peta secara periodik untuk memperlihatkan titik koordinat terbaru (posisi akhir dari peta).

5. User melihat titik-titik koordinat halte dan bus untuk memperlihatkan posisi masing-masing objek halte dan bus.

\section{HASIL DAN PEMBAHASAN}

Adapun hasil dan pembahasan dari penelitian yang telah dilaksanakan adalah :

a. Analisis Sistem

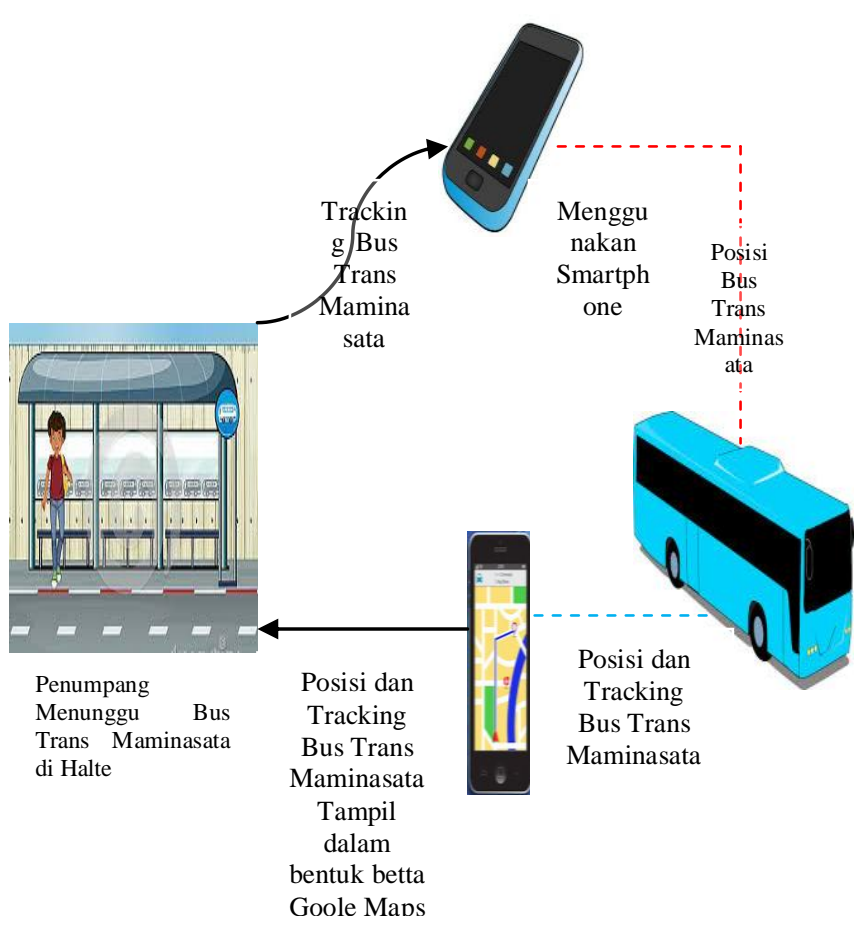

Gambar 4. Analisis Sistem

Gambar 4 menjelaskan mengenai calon penumpang yang sedang menunggu di halte yang telah disiapkan menggunakan perangkat smartphone kemudian membuka aplikasi mobile web, pada sistem calon penumpang dapat memilih koridor sesuai dengan yang akan dilalui dimana halte penumpang tersebut berada, setelah memilih koridor maka akan di tampilkan peta Google Maps API serta menampilkan informasi rute yang dilalui bus Trans Mamminasata setelah itu melihat rute yang dilalui dan memperlihatkan tracking keberadaan bus Trans Mamminasata. 


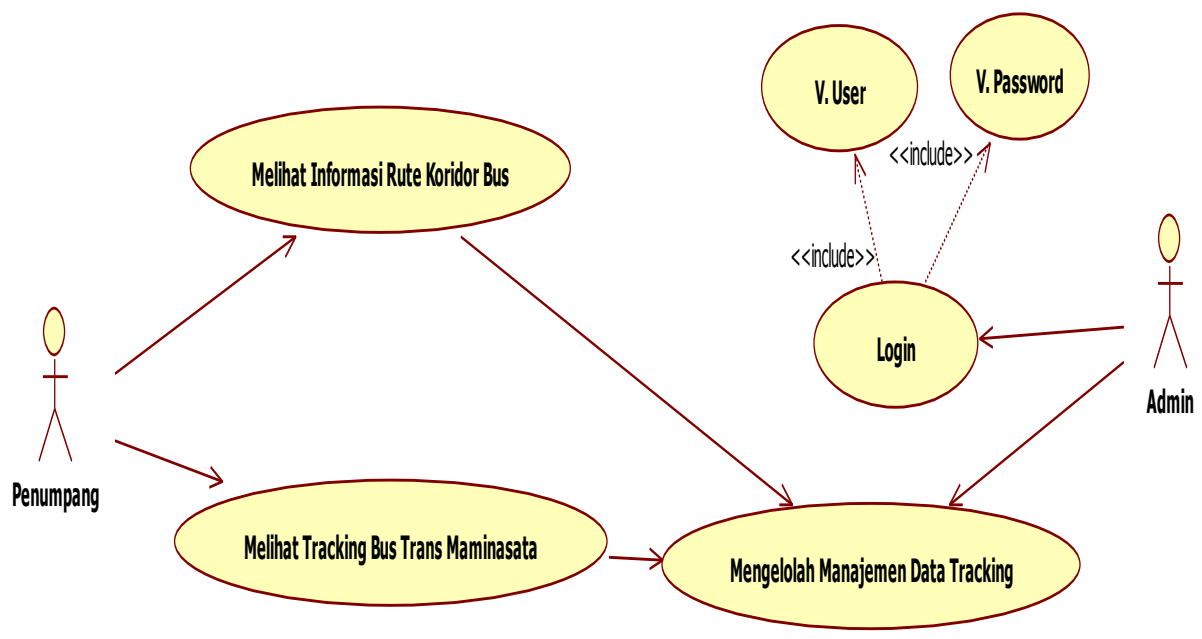

Gambar 5. Use Case Diagram Sistem

Pada gambar 5 menjelaskan mengenai use case diagram dari sistem tracking yang dimana terdapat 2 aktor yaitu calon penumpang dan admin dari sistem. Para calon penumpang dapat melakukan kegiatan melihat informasi koridor bus yaitu rute bus yang dilalui oleh Bus Trans Mamminasata, kemudian penumpang atau calon penumpang yang menunggu di halte bus setelah melihat info rute pada data koridor maka para penumpang dapat melihat tracking dari bus Trans Maminasata yaitu melihat keberadaan atau posisi bus Trans Mamminasata. Pada aktor admin melakukan kegiatan login ke sistem dan mengelolah data-data manajemen yang berkaitan dengan sistem tracking Bus Trans Mamminasata.

\section{c. Sequence Diagram}

Sequence diagram atau diagram kegiatan yang dari penumpang yang dimana terdapat beberapa objek yaitu aktor dari penumpang, objek sistem, list koridor dan peta. Dari kegiatan tersebut penumpang masuk kedalam sistem kemudian melihat list koridor dari bus Trans Mamminasata dan menpilkan informasi rute koridor bus, setelah itu memilih salah satu koridor di mana tempat atau halte berada bus berada. Selanjutnya akan ditampilkan peta yang memperlihatkan jalur tracking dari bus Trans Mamminasata, dapat dilihat pada gambar 6 sebagai berikut :

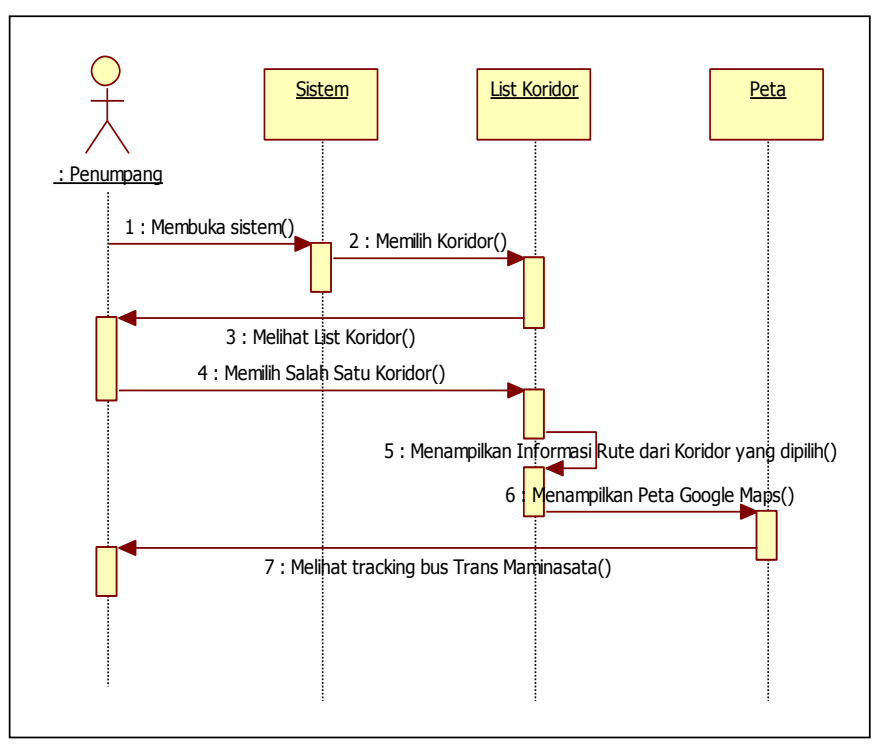

Gambar 6. Sequence Diagram 


\section{d. Activity Diagram}

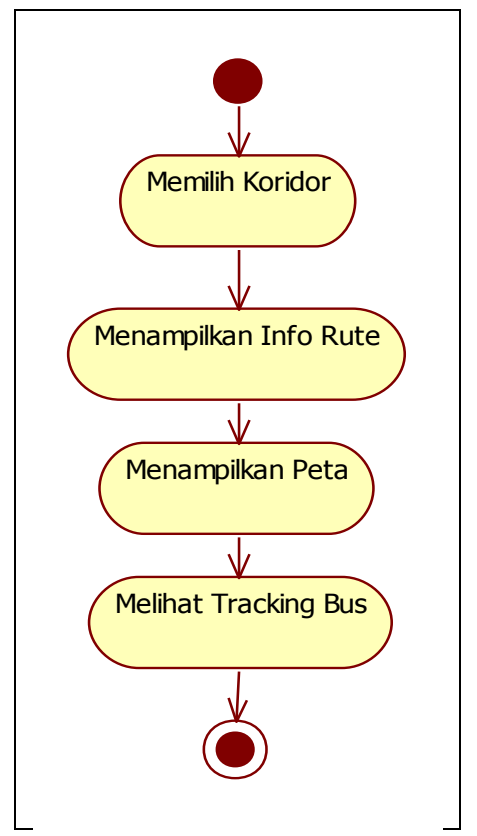

Gambar 7. Activity Diagram

Pada gambar 7 menjelaskan mengenai activity diagram dari sistem yang dimana aktivitas yang dilakukan yaitu memilih salah satu koridor, kemudian melihat informasi rute dari koridor yang dipilih setelah itu peta tampil dan menampilkan rute serta tracking dari bus Trans Mamminasata.

e. Tampilan Login Admin Bus Trans Mamminasata

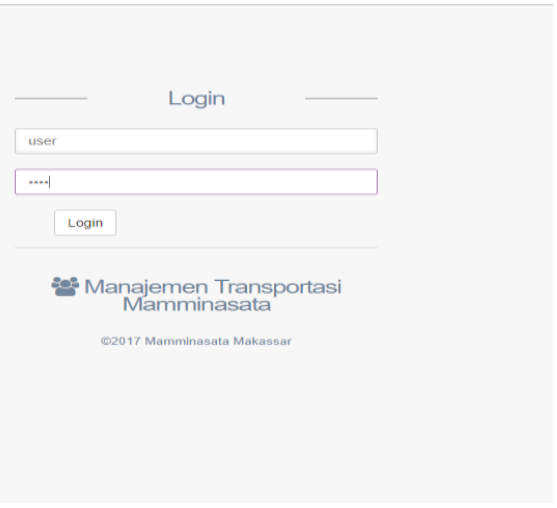

Gambar 8. Login Admin

Pada gambar 8 menjelaskan rancangan tampilan dari login admin terhadap sistem, yang dimana admin menginputkan user dan password kemudian mengklik tombol login. f. Tampilan Profil Operator Admin

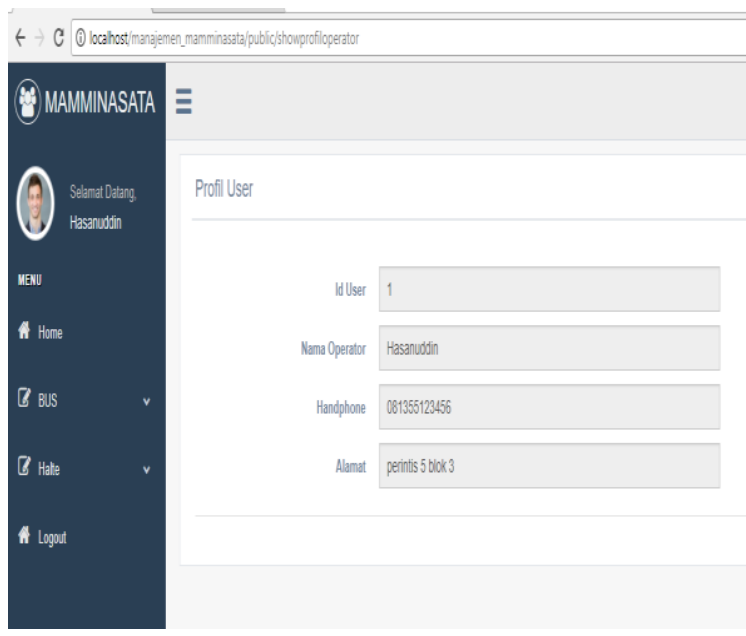

Gambar 9. Profil Operator Admin

\section{g. Input Data Bus}

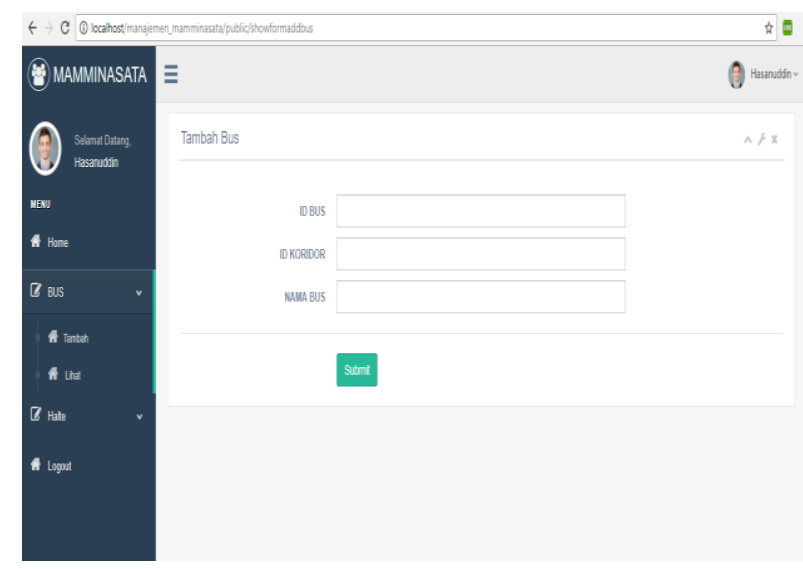

Gambar 10. Input Data Bus

Pada gambar 10 menjelaskan menjelaskan rancangan form untuk menambah data bus Trans Mamminasata.

h. Tampilan List Bus

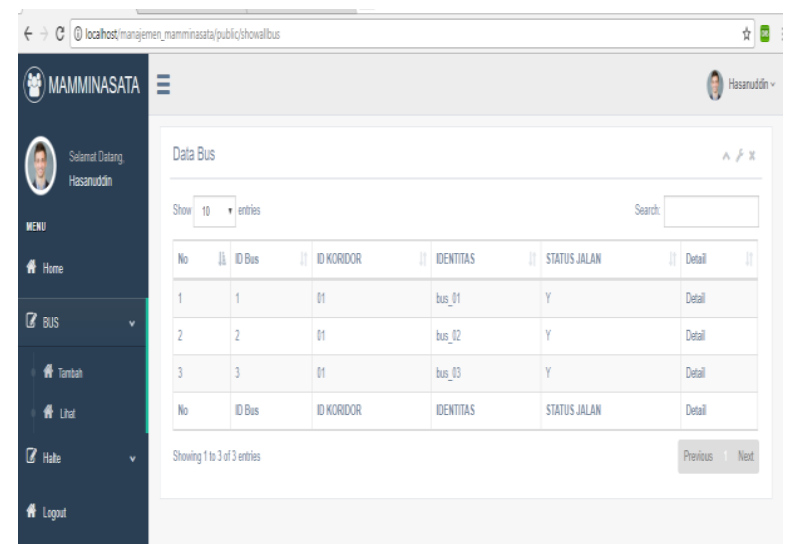

Gambar 11. Tampilan List Bus 
Pada gambar 11 menjelaskan mengenai list bus Trans Mamminasata dari bus pada setiap koridor.

\section{i. Tambah Data Halte}

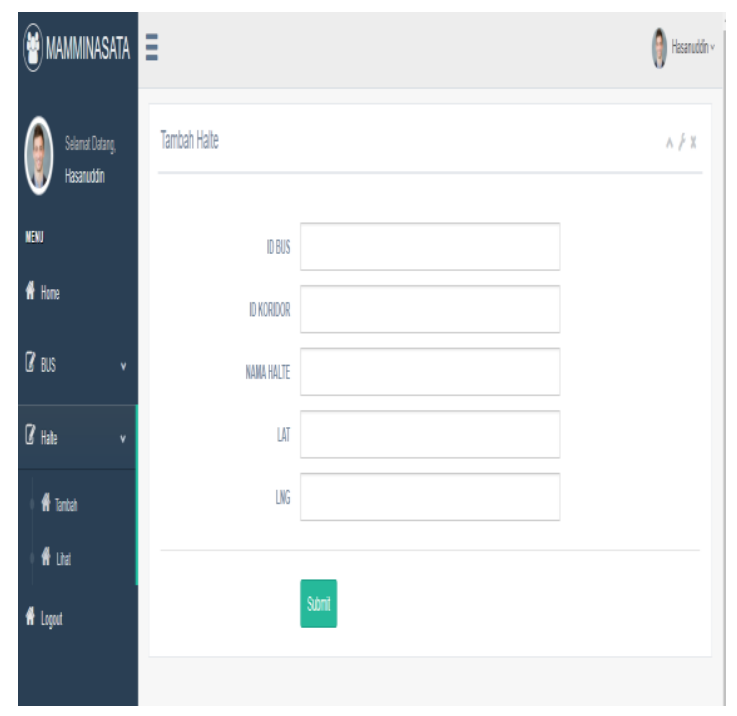

Gambar 12. Tambah Data Halte

Gambar 12 menjelaskan tambah data halte yang dimana akan di inputkan id bus, id koridor, nama halte dan meninputkan titik koordinatnya.

j. Tampilan List Halte

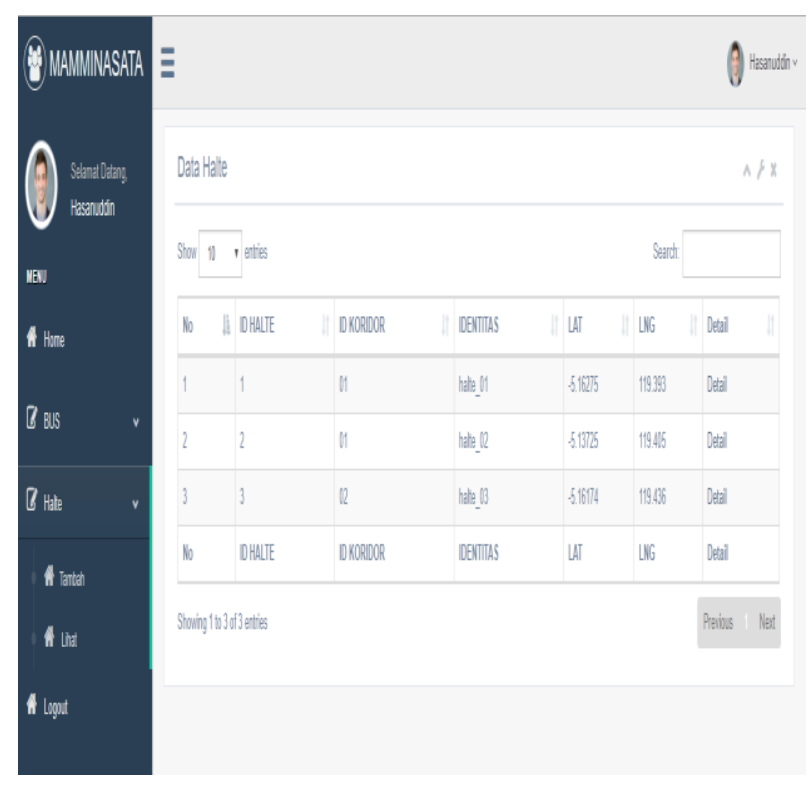

Gambar 13. List Halte
Pada gambar 13 menjelaskan mengenai list dari data halte yang dilalui dari setiap koridor.

\section{k. Tampilan Home Pada Sistem Mobile Penumpang}

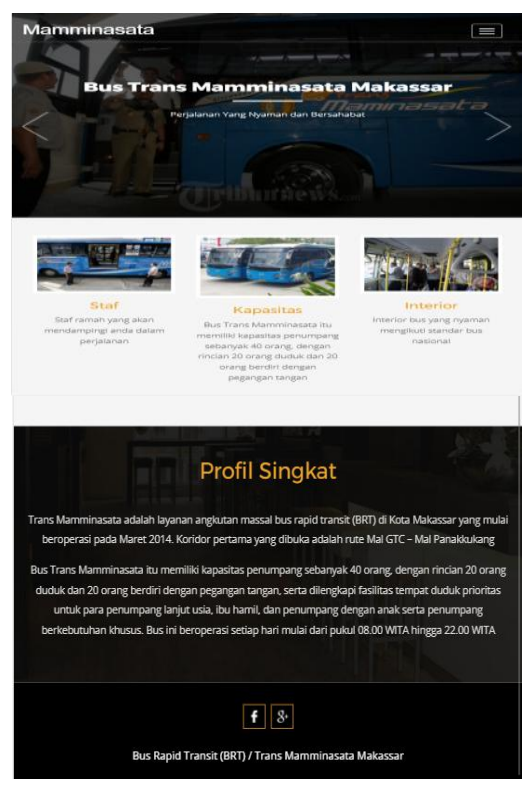

Gambar 14. Tampilan Home

Pada gambar 14 menjelaskan tampilan home atau beranda pada sistem pada penumpang yang berbasis mobile web.

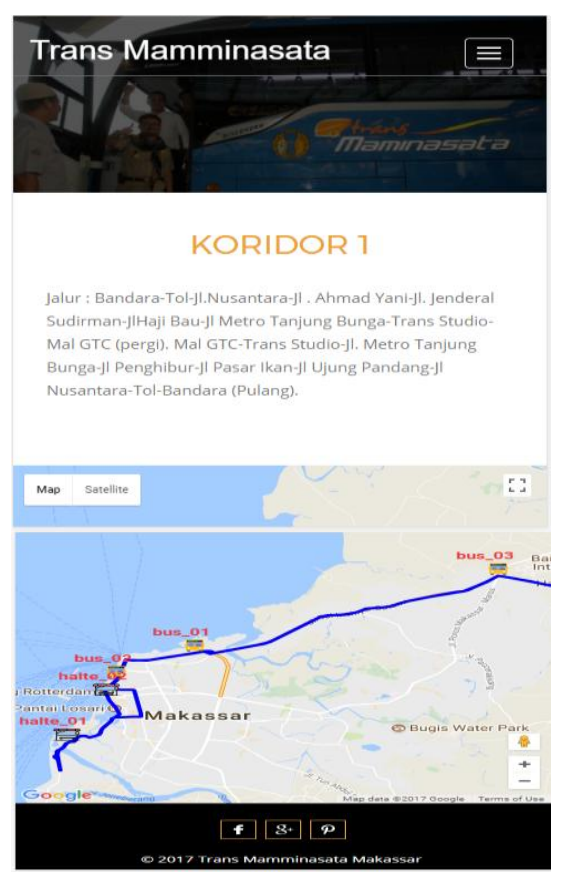

Gambar 15. Tracking Bus 
Pada gambar 15 menjelaskan proses mengenai tracking pada bus Trans Mamminasata yang di tampilkan pada peta .

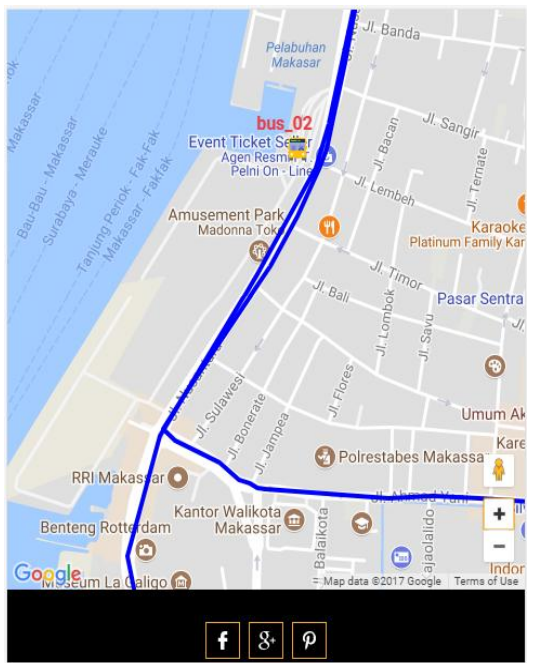

Gambar 16. View Zoom Peta Tracking

Pada gambar 16 menjelaskan view zoom dari peta tracking dari Bus trans Maminasata.

\section{Pengujian}

Berdasarkan pengujian Blackbox yang telah dilakukan maka secara umum hasil pengujian aplikasi dapat disimpulkan sebagai berikut :

Tabel 3. Pengujian Blackbox

\begin{tabular}{|c|c|c|c|}
\hline No & $\begin{array}{l}\text { Skenario } \\
\text { Pengujian }\end{array}$ & $\begin{array}{l}\text { Hasil yang } \\
\text { diharapkan }\end{array}$ & Kesimpulan \\
\hline 1 & Login Admin & $\begin{array}{l}\text { Berhasil Login ke } \\
\text { dalam admin siste } \\
\text { web }\end{array}$ & Valid \\
\hline 2 & $\begin{array}{l}\text { Tambah Data } \\
\text { Bus }\end{array}$ & $\begin{array}{l}\text { Berhasil } \\
\text { menambah data } \\
\text { bus }\end{array}$ & Valid \\
\hline 3 & $\begin{array}{l}\text { Tambah Data } \\
\text { Halte }\end{array}$ & $\begin{array}{l}\text { Berhasil } \\
\text { menambah Data } \\
\text { halte }\end{array}$ & Valid \\
\hline 4 & $\begin{array}{l}\text { Menampilkan } \\
\text { Tracking bus } \\
\text { pada setiap } \\
\text { koridor }\end{array}$ & $\begin{array}{l}\text { Berhasil } \\
\text { menampilkan } \\
\text { tracking bus pada } \\
\text { setiap koridor }\end{array}$ & Valid \\
\hline
\end{tabular}

Hasil pengujian non fungsional yang disimpulkan sebagai berikut :
Tabel 4. Pengujian Non Fungsional

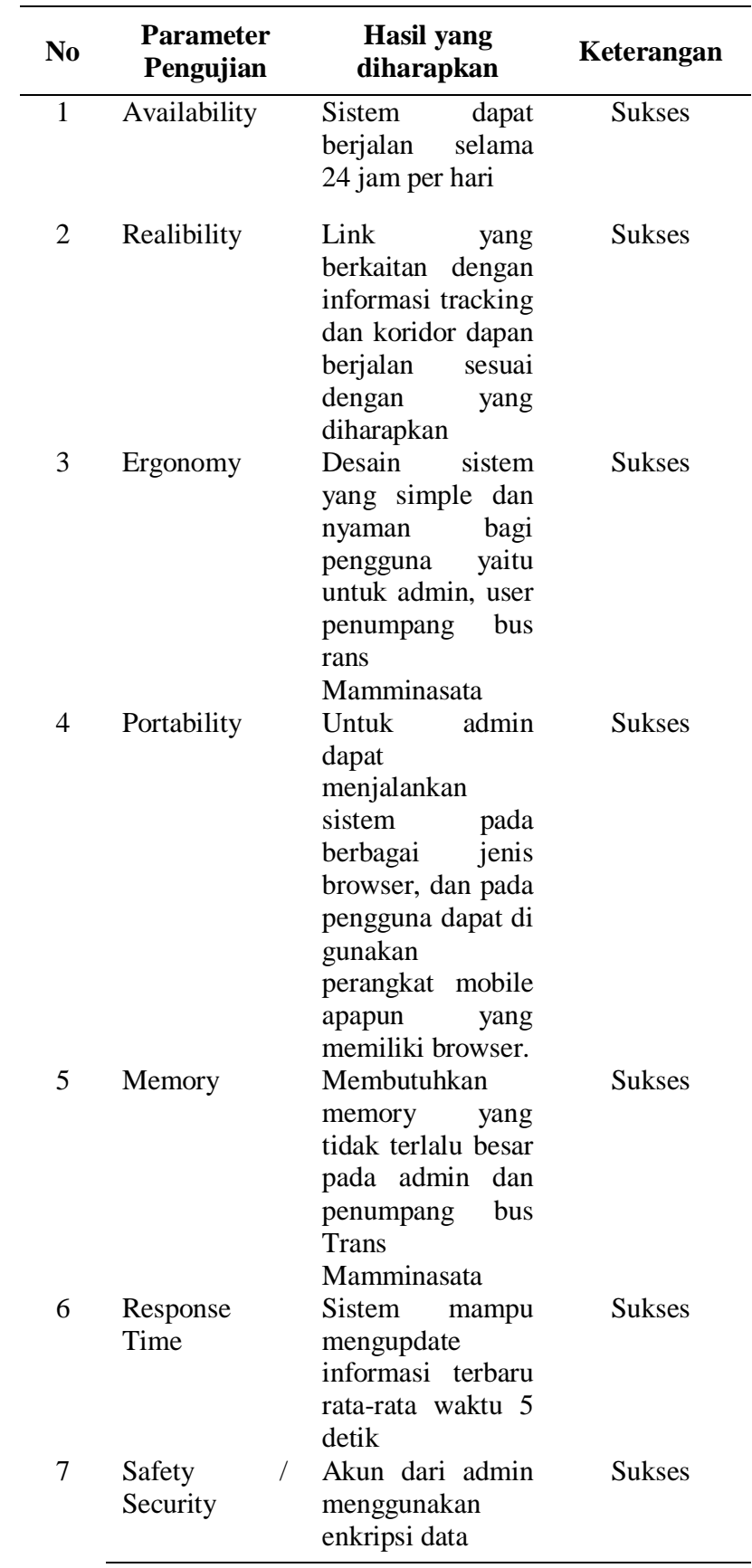

Selanjutnya diadakan pengujian kuesioner untuk mengetahui seberapa bermanfaat sistem terhadap pengguna yaitu penumpang bus Trans Mamminasata, dimana terdapat 10 soal yang diberikan kepada 25 responden yaitu para penumpang bus Trans Mamminasata yang lagi menunggu bus di halte yang tersebar di beberapa 
tempat kota Makassar. Dari hasil kuesioner di peroleh hasil sebagai berikut :

Tabel 5. Rata-rata Persentase dari Kuesioner

\begin{tabular}{cc}
\hline Alternatif Jawaban & $\begin{array}{c}\text { Rata-Rata } \\
\text { Presentase }\end{array}$ \\
\hline Sangat Bermanfaat & 82 \\
Bermanfaat & 15 \\
Cukup Bermanfaat & 3 \\
Tidak Bermanfaat & 0 \\
\hline Total & $\mathbf{1 0 0}$ \\
\hline
\end{tabular}

Dari tabel 5 menjelaskan hasil hitung ratarata persentase dari ke 25 responden dimana terdapat $82 \%$ menyatakan sangat bernanfaat, $15 \%$ bermanfaat, $3 \%$ cukup bermanfaat dan $0 \%$ tidak bermanfaat. Untuk lebih jelasnya dapat di lihat pada diagram sebagai berikut :

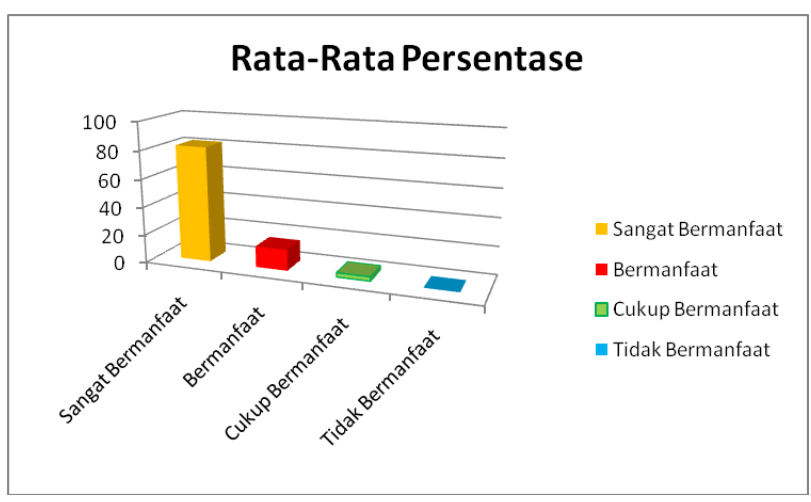

Gambar 17. Rata-rata Persentase Hasil Kuesioner

Pada gambar 17 menjelaskan bentuk diagram dari hasil kuesioner yang telah di bagikan kepada penumpang bus Trans Mamminasata yang dimana terlihat pada gambar balok yang berwarna kuning dengan keterangan sangat bermanfaat yang lebih di pilih oleh para responden.

Berdasarkan hasil kuesioner yang telah diperoleh yang menyatakan bahwa sistem tracking bus Trans Mamminasata sangat bermanfaat bagi masyarakat pengguna moda tersebut, sehingga masyarakat sangat terbantu dengan adanya sistem tersebut apalagi sekarang ini keadaan dijalan yang tak menentu yang terkadang macet. Sistem tracking bus Trans Mamminasata memberikan solusi kepada masyarakat agar mereka mengetahui keberadaan atau pun tracking dari bus Trans Mamminasata.

Pemrograman yang digunakan untuk membangun sistem tracking adalah pemrograman web dengan database mysql, dimana pemrograman tersebut di koneksikan dengan teknologi Google Maps API. Pada tampilan peta Google Maps API ini pula dibuat rute dari tracking bus Trans Mamminasata. Kemudian untuk data-data yang telah dibuat seperti data bus dan data halte tersimpan dalam database.

\section{PENUTUP}

Adanya sistem tracking bus Trans mamminasata, masyarakat dapat membantu para penumpang untuk mengetahui keberadaan bus yang akan ditumpangi secara periodik dan real time serta dapat menampilkan tracking ke bentuk peta Google Maps API berbasis mobile web. Berdasarkan hasil pengujian fungsional di peroleh hasil yang valid, sistem telah berjalan sesuai dengan hasil test factor yang diharapkan. Pada pengujian non fungsional berdasarkan aspek availability, sistem dapat berjalan selama 24 jam, reability yaitu link-link pada sistem dapat di akses keseluruhan, ergonomy yaitu memiliki desain dan tampilan simpel sehingga mudah di gunakan para penumpang bus Trans Mamminasata, portability yaitu sistem untuk admin dapat di buka pada browser manapun dan pengguna sistem tracking dapat menggunakan di perangkat mobile apapun termasuk smartphone yang memiliki browser, memory yaitu memory yang tidak terlalu besar pada admin dan 
pengguna sistem tracking bus Trans Mamminasata, response time yaitu dapat mengupdate informasi dalam 5 detik dan safety/security yaitu password admin digunakan enkripsi agar data admin tidak dapat di tembus oleh pihak luar.

Saran untuk pengembangan penelitian tersebut adalah di sediakan notifikasi dan informasi pada setiap halte berupa layar komputer yang dipasang di halte, yang dapat mengetahui informasi tracking bus Trans Mamminasata tidak hanya penumpang yang memiliki perangkat mobile tetapi juga bisa digunakan untuk penumpang yang tidak memiliki perangkat mobile.

\section{UCAPAN TERIMA KASIH}

Terima kasih kepada DPRM SIMLITABMAS Kementrian RISTEK DIKTI yang telah memberikan dana untuk penelitian ini sehingga penelitian ini dapat tercapai dan berjalan lancar, terima kasih juga kepada Dinas Pehubungan kota Makassar dan Perum Damri Makassar yang banyak membantu penulis dalam memberikan informasi pada saat pengumpulan data sehingga apa yang menjadi tujuan penelitian dapat tercapai. Terima kasih pula kepada semua teman dan keluarga yang banyak membantu dan segala pengertinnya serta kepada semua yang terlibat dalam penelitian ini baik secara langsung ataupun tidak langsung yang tidak dapat penulis ucapkan satu persatu.

\section{DAFTAR PUSTAKA}

Dirgahayani, P. (2013). Environmental co-benefits of public transportation improvement initiative: the case of Trans-Jogja bus system in Yogyakarta, Indonesia. Journal of Cleaner Production, 58(Supplement C), 74-81. https://doi.org/10.1016/j.jclepro.2013.07.013
Firmanda, D. R., \& Rahardjo, N. (2013). Sistem Informasi Geografi Untuk Evaluasi Lokasi Shelter Bus Trans Semarang. Jurnal Bumi Indonesia, 2(3). Retrieved from http://lib.geo.ugm.ac.id/ojs/index.php/jbi/article /view/211

Haroen, Z.A., Miskul Firdaus, Zaini, M., 2014. 113821ID-tingkat-kepuasan-pengguna-bus-transjaka.pdf. J. Manaj. Transp. Logist. 1.

Hidayat, S. S., Kencana, I. P. E. N., \& Jayanegara, K. (2013). Prediksi Pengguna Bus Trans Sarbagita Dengan Metode Adaptive Neuro Fuzzy Inference System. E-Jurnal Matematika, 2(3), 46-52. https://doi.org/10.24843/MTK.2013.v02.i03.p0 48

Inilah Koridor Busway Makassar - JPNN.COM. (n.d.). Retrieved October 11, 2017, from https://www.jpnn.com/news/inilah-koridorbusway-makassar

Isya, M., Anggraini, R., Sriana, T., 2013. Pemodelan Pemilihan Moda Antara Bus Rapid Transit Dan Sepeda Motor Dalam Perjalanan Menuju Ke Kampus Dengan Teknik Stated Preference. J. Tek. Sipil 2, 225-236.

Ridwan. (2017). Estimasi waktu kedatangan bus rapid transit (brt) menggunakan bus sebagai sensor node dikota makassar - pdf. Jurnal instek, 2(2). Retrieved from http://docplayer.info/49163718Estimasi-waktu-kedatangan-bus-rapid-transitbrt-menggunakan-bus-sebagai-sensor-nodedikota-makassar.html

Rismayani, R. (2016). Pemanfaatan Teknologi Google Maps Api Untuk Aplikasi Laporan Kriminal Berbasis Android Pada Polrestabes Makassar. Jurnal Penelitian Pos Dan Informatika, 6(2), 185-200. https://doi.org/10.17933/jppi.2016.060205

Rismayani, R., \& Ardimansyah, A. (2016.). Aplikasi Berbasis Mobile untuk Pencarian Rute Angkutan Umum Kota Makassar Menggunakan Algoritma Depth First Search. Retrieved from https://jurnal.kominfo.go.id/index.php/pekomm as/article/view/306

Ritonga, P.,(2015). Pengertian Unified Modeling Language ( UML ) dan Modelnya Menurut Pakar. Web Program. Dan SEO.

Safaat, N., 2015. Android: Pemrograman Aplikasi Mobile Smartphone dan Tablet PC Berbasis Android, Revisi Kedua. Informatika.

Salasa, W., Wakhidho, H., Bagus Hario Setiadji, \& Epf. Eko Yulipriyono. (2015). Evaluasi Sistem Pelayanan Transit Antar Koridor Bus Rapid Transit Trans Semarang. JURNAL KARYA TEKNIK SIPIL, 4(4), 501-511.

Sy, H., \& Rismayani, R. (2015). Pemetaan Titik Perumahan Pada Kota Makassar Menggunakan Google Maps Api. SEMNASTEKNOMEDIA ONLINE, 3(1), 4-713. 